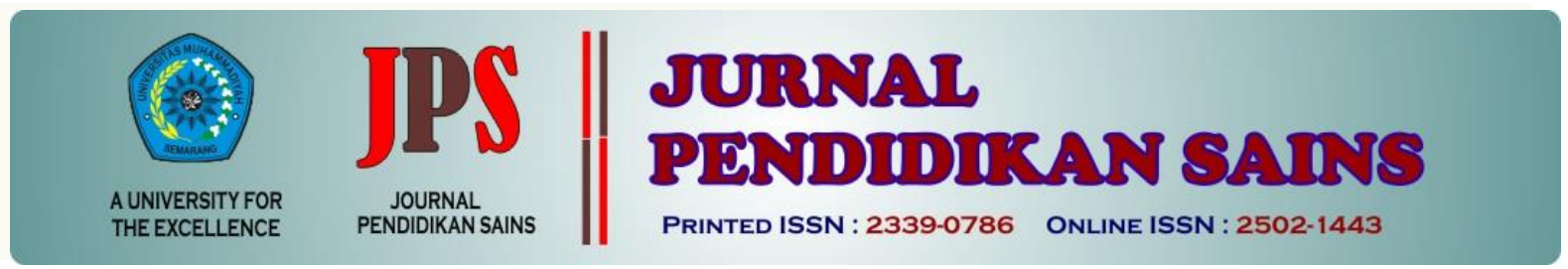

http://jurnal.unimus.ac.id/index.php/JPKIMIA

\title{
PENGEMBANGAN INTEGRATED SCIENCE ASSESMENT BERBASIS PISA UNTUK PESERTA DIDIK KELAS VII SMP
}

Oleh:

Indri Nurwahidah $^{1}$, Yeni Widiyawati ${ }^{2}$, Dwi Septiana Sari ${ }^{3}$

${ }^{123}$ Prodi Pendidikan IPA, Fakultas Sains dan Teknologi, Universitas Ivet

\begin{tabular}{ll}
\hline Article history & Abstract \\
\hline $\begin{array}{l}\text { Submission }: \text { 2019-06-12 } \\
\text { Revised }\end{array}: \begin{array}{l}\text { This study aims to develop an integrated science assessment based on } \\
\text { Accepted }\end{array}:$ 2019-08-07-07 & $\begin{array}{l}\text { PISA in Class VII IPA material. This type of research is Borg \& Gall's } \\
\text { research and development. The assessment was developed in the form } \\
\text { of reasoned multiple choice questions in odd grade VII grade science } \\
\text { material. The questions of integrated science assessment were } \\
\text { developed based on themes that are closely related to the daily lives of } \\
\text { Keyword: }\end{array}$ \\
$\begin{array}{l}\text { Kata kunci: integrated } \\
\text { science assessment, literasi } \\
\text { sains, PISA }\end{array}$ & $\begin{array}{l}\text { high school science teachers for the components of content, } \\
\text { presentation, and language, it can be concluded that the instruments } \\
\text { developed were valid with very good categories. Thus, integrated } \\
\text { science assessment based on PISA is appropriate for use in learning. }\end{array}$ \\
\hline
\end{tabular}

\section{Pendahuluan}

Penerapan pembelajaran IPA menekankan pada prinsip, konsep, serta keterkaitannya dalam kehidupan sehingga peserta didik memiliki nilai tanggung jawab dan kepedulian terhadap lingkungan (Saptono, Rustaman, Saefudin, \& Widodo, 2013; Lathifah \& Wilujeng, 2016; Situmorang, 2017; Rahmawati, Hartono, \& Nugroho, 2015). Penggolongan ilmu IPA secara umum terbagi menjadi fisika, kimia, dan biologi (Rohmawati, Widodo, \& Agustini, 2018; Mardhiyyah, Rusilowati, \& Linuwih, 2016), akan tetapi pembelajaran IPA di SMP seharusnya disampaikan dalam satu kesatuan yang utuh dan saling memiliki keterkaitan antar materi untuk mengembangkan pengalaman peserta didik dalam memahami alam sekitar (Ranaweera, 1976; Listyawati, 2012). Pembelajaran IPA yang terintegrasi dapat menamankan kepedulian peserta didik terhadap lingkungan sekitar melalui penerapan ilmu yang dimilikinya (Lathifah \& Wilujeng, 2016; Ristina, Linuwih, \& Nuswowati, 2018). Kenyataannya, penerapan pembelajaran IPA terpadu di SMP belum terlaksana secara maksimal karena penyajiannya masih terpisah antar bidang kajian IPA (Yuliati, 2013). Selama ini pelaksanaan pembelajaran IPA belum sepenuhnya terintegrasi serta belum banyak guru IPA yang mengembangkan bahan ajar maupun penilaian integrated science (Sukardiyono \& Rosana, 2018; Yuliati, 2013). Hal ini menyebabkan kemampuan literasi sains seperti tujuan pembelajaran yang diharapkan pada kurikulum 2013 belum dapat tercapai dengan baik. Kemampuan tersebut dikaji pada studi bertaraf internasional melalui Programme for International Student Assessment (PISA).

PISA diselenggarakan oleh Organization for Economic Cooperation and Development (OECD). Studi ini mengkaji kemampuan berpikir peserta didik. Kemampuan tersebut perlu diukur dengan memberikan penilaian yang sesuai dengan materi yang

*Corresponding Author:

$\begin{array}{ll}\text { Nama } & \text { : Indri Nurwahidah } \\ \text { Lembaga } & \text { : Universitas Ivet } \\ \text { Email } & \text { : indrinur555@gmail.com }\end{array}$ 
disampaikan (Nurwahidah, 2017), sehingga dapat menjadi feedback untuk pelaksanaan pembelajaran selanjutnya. Soal-soal yang diujikan pada PISA menuntut peserta didik untuk mampu melakukan penalaran, pemecahan masalah, analisis, dan evaluasi dalam penyelesaiannya (Setiawan et al., 2014; Wardhani, 2008). Hasil survei PISA tahun 2015 menempatkan Indonesia pada peringkat 8 terbawah dari 72 negara peserta. Hal ini menunjukkan bahwa literasi sains peserta didik Indonesia masih rendah (Basam, Rusilowati, \& Ridlo 2016). Fakta tersebut dapat dijadikan gambaran bahwa proses pembelajaran sains di Indonesia masih perlu perbaikan (Sumarti, Rahayu, \& Madlazim, 2015). Haristy, Enawaty, dan Lestari (2013) menambahkan bahwa sebagian besar peserta didik masih kesulitan memahami dan menerapkan konsep sains untuk menyelesaikan permasalahan dalam kehidupan sehari-hari, serta belum terbiasa menyelesaikan soal yang membutuhkan penalaran (Nurwahidah, 2018) sehingga kemampuan literasi sains peserta didik di Indonesia cenderung masih rendah. Dengan literasi sains peserta didik mampu mengenal lingkungan sekitar, terlibat dalam proses sains, dapat menginvestigasi pertanyaan, serta mengambil kesimpulan dari bukti yang ada (Lutfi, Ismail, \& Azis, 2017). Kemampuan literasi sains yang baik pada peserta didik dapat membuat pembelajaran sains lebih bermakna dan optimal (Rakhmawan, Setiabudi, \& Mudzakir, 2015).

Pada proses pembelajaran, guru tidak hanya bertanggung jawab dalam penyampaian materi saja, tetapi juga harus memantau perkembangan kemampuan peserta didik serta ketercapaian tujuan pembelajaran yang telah ditentukan. Oleh karena itu, guru harus menggunakan asesmen yang sesuai agar perkembangan perserta didik dapat dipantau secara berkelanjutan serta masalah-masalah yang muncul dalam pembelajaran dapat diupayakan pemecahannya. Pada kenyataannya, sebagian guru IPA mengalami kesulitan dalam menyusun dan melaksanakan asesmen pada pembelajaran (Kurniawan \& Triharsiwi, 2016; Tihardila, Marpaung, \& Achmad, 2018). Oleh karena itu, guru perlu mengevaluasi pencapaian kemampuan peserta didik dengan baik sebagai refleksi kegiatan pembelajaran yang dilakukan sehingga dapat menjadi masukan dalam merancang kegiatan pembelajaran yang efektif. Namun, evaluasi integrated science masih jarang dikembangkan oleh guru pada pembelajaran IPA SMP sehingga literasi sains peserta didik kurang dapat terukur dengan baik. Pengembangan integrated science assessment berbasis PISA perlu dilakukan mengingat karakteristik soal PISA yang menuntut kemampuan dalam melakukan penalaran, pemecahan masalah, analisis, dan evaluasi peserta didik pada penyelesaiannya. Tujuan dilakukan penelitian ini yaitu untuk menghasilkan integrated science assesment berbasis PISA untuk peserta didik SMP.

\section{Metode Penelitian}

Penelitian ini merupakan penelitian pengembangan yang mengadaptasi model dari Borg \& Gall. Namun, penelitian ini hanya dilakukan sampai langkah ketujuh dari kesepuluh langkah dalam penelitian dan pengembangan model Borg \& Gall.

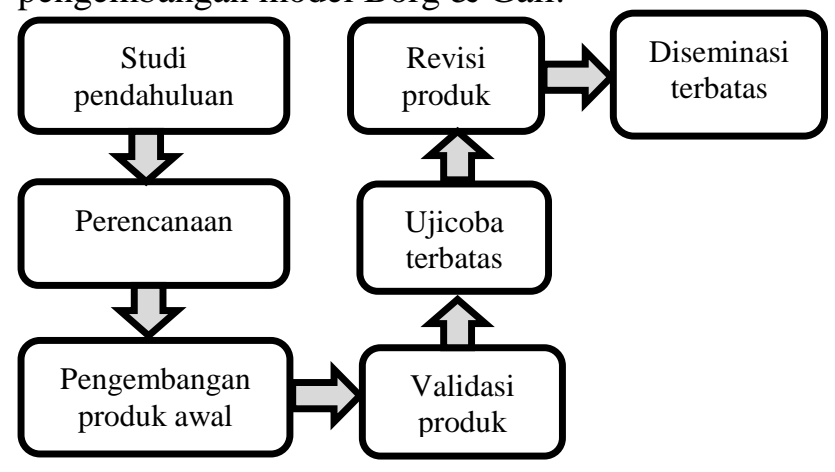

Gambar 1. Prosedur Penelitian

Prosedur penelitian dilaksanakan dalam tujuh tahapan, yaitu (1) studi pendahuluan, (2) perencanaan, (3) pengembangan produk awal, (4) validasi produk, (5) ujicoba terbatas, (6) revisi produk untuk menghasilkan produk utama, (7) disesminasi terbatas.

Tahap studi pendahuluan meliputi studi literatur dan analisis kebutuhan. Analisis kebutuhan digunakan untuk mengumpulkan informasi kebutuhan guru dan sekolah mengenai asesmen integrated science. Studi literatur digunakan sebagai sarana untuk memecahkan masalah yang ditemui di lapangan berdasarkan informasi yang diperoleh, yaitu dengan mengkaji soal-soal PISA serta sumber pustaka yang relevan dengan penelitian

Pada tahap perencanaan dilakukan pemetaan kompetensi mata pelajaran IPA kelas VII, mengumpulkan bahan-bahan materi dan referensi bentuk soal dari PISA. Selanjutnya menyusun indikator soal dan kisi-kisi soal sesuai kompetensi pada mata pelajaran IPA kelas VII Kurikulum 2013 dan draft indikator soal PISA Rincian nomor soal asesmen 
integrated science berbasis PISA disajikan pada $\quad$ Tabel 1.

Tabel 1. Rincian Nomor Soal Integrated Science Assessment berbasis PISA

\begin{tabular}{|c|c|c|}
\hline Kompetensi & Indikator & Nomor Soal \\
\hline \multirow[t]{4}{*}{$\begin{array}{l}\text { Menjelaskan } \\
\text { fenomena ilmiah }\end{array}$} & $\begin{array}{l}\text { Mengingat kembali dan mengaplikasikan pengetahuan } \\
\text { ilmiah yang sesuai untuk penyelesaian permasalahan }\end{array}$ & $\begin{array}{l}2,3,10,13,16, \\
20,25,26,27,30\end{array}$ \\
\hline & Membuat dan menilai prediksi yang benar & 11,29 \\
\hline & Menyusun hipotesis penjelas suatu fenomena & 6,8 \\
\hline & $\begin{array}{l}\text { Menjelaskan potensi implikasi dari suatu pengetahuan } \\
\text { ilmiah untuk masyarakat }\end{array}$ & 22 \\
\hline \multirow{2}{*}{$\begin{array}{l}\text { Mengevaluasi } \\
\text { dan mendesain } \\
\text { penyelidikan } \\
\text { ilmiah }\end{array}$} & $\begin{array}{l}\text { Memilih rumusan masalah yang dapat diselidiki secara } \\
\text { ilmiah. }\end{array}$ & \\
\hline & $\begin{array}{l}\text { Mendesain cara-cara untuk menyelesaikan suatu } \\
\text { permasalahan secara ilmiah. }\end{array}$ & 21,24 \\
\hline \multirow{5}{*}{$\begin{array}{l}\text { Menginterpretasi } \\
\text { kan data dan } \\
\text { bukti } \\
\text { ilmiah }\end{array}$} & Mengubah bentuk representasi data & 1,14 \\
\hline & $\begin{array}{l}\text { Menganalisis dan menginterpretasi data serta menyusun } \\
\text { kesimpulan yang tepat }\end{array}$ & $9,30,34,35$ \\
\hline & $\begin{array}{l}\text { Mengidentifikasi asumsi, bukti, dan alasan berdasarkan } \\
\text { kasus sains yang disajikan }\end{array}$ & $15,17,18$ \\
\hline & $\begin{array}{l}\text { Mengelompokkan argumen berdasarkan bukti dan teori } \\
\text { ilmiah dan non ilmiah }\end{array}$ & $4,5,31,32,33$ \\
\hline & $\begin{array}{l}\text { Mengevaluasi argumen dan bukti ilmiah dari berbagai } \\
\text { sumber }\end{array}$ & $7,12,19,28$ \\
\hline
\end{tabular}

Tahap selanjutnya yaitu pengembangan produk awal. Asesmen integrated science yang dikembangkan berupa 35 butir soal pilihan ganda beralasan untuk materi IPA kelas VII. Soal dikembangkan sesuai dengan indikator PISA. Selain itu, juga dilakukan penyusunan angket validasi asesmen integrated science berbasis PISA yang meliputi komponen isi, penyajian dan bahasa. Angket disusun menggunakan skala Likert dengan empat pilihan jawaban.

Angket validasi ditujukan kepada ahli materi, ahli evaluasi dan guru IPA SMP. Selanjutnya, dilakukan ujicoba terbatas berupa uji keterbacaan kepada peserta didik guna mendapat informasi apakah asesmen yang dikembangkan mudah dipahami dan untuk mengetahui respon peserta didik. Ujicoba terbatas dilaksanakan di MTs Al Khoiriyyah dengan jumlah 20 orang peserta didik kelas VII yang dipilih secara acak. Setelah pelaksanaannya selesai, peserta didik diminta untuk memberikan kritik dan saran mengenai integrated science assessment berbasis PISA.

Validasi instrumen integrated science assesment berbasis PISA dilakukan oleh guru IPA SMP SMP Nurul Islam dan MTs Al Khoiriyyah Semarang karena kedua guru IPA tersebut sudah mengikuti Program Profesi Guru (PPG) IPA sehingga diasumsikan sangat memahami tentang pembelajaran IPA terpadu di SMP serta penerapan HOTS sebagai kompetensi yang diharapkan pada kurikulum 2013. Uji keterbacaan juga dilakukan di MTs Al Khoiriyyah karena peserta didik di sekolah tersebut sudah terbiasa dengan pembelajaran IPA yang disampaikan secara terpadu.

Tahap selanjutnya yaitu revisi produk untuk menghasilkan produk utama. Pada tahap ini dilakukan analisis data dan revisi produk berdasarkan masukan yang diberikan validator, guru IPA dan peserta didik agar lebih mudah dipahami peserta didik. Selanjutnya, produk integrated science assessment disebarluaskan (diseminasi) kepada guru IPA di beberapa SMP/MTs. Asesmen tersebut diharapkan dapat digunakan sebagai instrumen evaluasi proses pembelajaran IPA.

Data skor hasil validasi asesmen integrated science yang diperoleh ditabulasi, dan dihitung skor rata-ratanya kemudian diubah menjadi data interval dengan skala empat. Acuan pengubahan skor disajikan pada Tabel 2. Sedangkan skor tanggapan peserta didik diubah menjadi data interval dengan dua kategori yaitu Baik (1) dan Tidak (0). 
Tabel 2. Konversi skor aktual menjadi nilai skala empat

(Direktorat Pembinaan SMA, 2010)

\begin{tabular}{lll}
\hline No & \multicolumn{1}{c}{ Interval Skor } & Kategori \\
\hline 1 & $\mathrm{Mi}+1,5 \mathrm{Sdi} \leq \bar{M} \leq \mathrm{Mi}+3,0$ & Sangat \\
& $\mathrm{Sdi}$ & Baik \\
2 & $\mathrm{Mi}+0 \mathrm{Sdi} \leq \bar{M}<\mathrm{Mi}+1,5$ & Baik \\
& $\mathrm{Sdi}$ & \\
3 & $\mathrm{Mi}-1,5 \mathrm{Sdi} \leq \bar{M}<\mathrm{Mi}+0 \mathrm{Sdi}$ & Cukup \\
4 & $\mathrm{Mi}-3 \mathrm{Sdi} \leq \bar{M}<\mathrm{Mi}-1,5 \mathrm{Sdi}$ & Kurang \\
\hline
\end{tabular}

keterangan :

$\mathrm{Mi}=$ mean ideal

Sdi $=$ standar deviasi ideal

Hasil konversi skor validasi asesmen integrated science dari ahli materi, ahli evaluasi dan guru IPA SMP disajikan pada Tabel 3, sedangkan untuk peserta didik disajikan pada tabel 4 .

Tabel 3. Hasil Konversi Skor Validasi Asesmen Integrated Science berbasis PISA dari Ahli Materi, Ahli Evaluasi dan Guru IPA SMP

\begin{tabular}{lll}
\hline Komponen & \multicolumn{1}{c}{ Interval skor } & Kategori \\
\hline Komponen & $65 \leq \bar{M} \leq 80$ & Sangat baik \\
isi & $50 \leq \bar{M}<65$ & Baik \\
& $35 \leq \bar{M}<50$ & Cukup \\
& $20 \leq \bar{M}<35$ & Kurang \\
\hline Komponen & $22,75 \leq \bar{M} \leq 28$ & Sangat baik \\
penyajian & $17,5 \leq \bar{M}<22,75$ & Baik \\
& $12,25 \leq \bar{M}<17,5$ & Cukup \\
& $7 \leq \bar{M}<12,25$ & Kurang \\
\hline Komponen & $13 \leq \bar{M} \leq 16$ & Sangat baik \\
bahasa & $10 \leq \bar{M}<13$ & Baik \\
& $7 \leq \bar{M}<10$ & Cukup \\
& $4 \leq \bar{M}<7$ & Kurang \\
\hline
\end{tabular}

Tabel 4. Hasil Konversi Skor Tanggapan Peserta Didik

\begin{tabular}{cll}
\hline No & \multicolumn{1}{c}{ Interval Skor } & \multicolumn{1}{c}{ Kategori } \\
\hline 1 & $8,25 \leq \bar{M} \leq 11$ & Sangat Baik \\
2 & $5,5 \leq \bar{M}<8,25$ & Baik \\
3 & $2,75 \leq \bar{M}<5,5$ & Cukup \\
4 & $0 \leq \bar{M}<2,75$ & Kurang \\
\hline
\end{tabular}

\section{Hasil Penelitian dan Pembahasan}

Langkah-langkah pengembangan integrated science assesment berbasis PISA dilakukan sesuai dengan tahapan Brog and Gall. Tahap pertama yaitu studi pendahuluan meliputi studi literatur dan analisis kebutuhan. Studi literatur dilakukan dengan cara mengumpulkan informasi yang relevan dengan integrated science assesment berbasis PISA serta melihat kekurangan dari penelitian yang terdahulu. Analisis kebutuhan dilakukan dengan cara melakukan wawancara dengan beberapa guru IPA SMP untuk mengumpulkan informasi tentang soal IPA terpadu yang ada di sekolah, kemampuan HOTS peserta didik, serta peran guru dala mengembangakan soal berbasis HOTS. Berdasarkan informasi yang diperoleh dari studi pendahuluan, belum banyak guru IPA yang sudah mengembangkan asesmen HOTS serta guru menyampaikan bahwa peserta didik belum terbiasa dalam mengerjakan tipe soal HOTS.

Tahap kedua yaitu melakukan perencanaan pengembangan integrated science assesment berbasis PISA, dengan cara melakukan mengumpulkan materi serta mempelajari bentuk soal berdasarkan PISA. Selanjutnya, kisi-kisi soal disusun sesuai dengan kompetensi pada mata pelajaran IPA kelas VII Kurikulum 2013 dan komponen PISA.

Tahap ketiga yaitu menyusun asesmen integrated science berdasarkan kisi-kisi soal. Contoh pengembangan soal pada asesmen integrated science disajikan pada Tabel 5. Contoh tampilan soal dapat dilihat pada Gambar 1 dan 2.

Integrated science assesment berbasis PISA yang dikembangkan berisi soal-soal pilihan ganda berjumlah 35 butir dan terdapat empat pilihan jawaban pada tiap soal. Untuk menjawab soal-soal tersebut peserta didik diharuskan menuliskan alasan dari setiap jawaban yang dipilih. Hal ini dimaksudkan untuk meminimalisir kemungkinan peserta didik hanya menebak pilihan jawaban yang disediakan tanpa tahu alasan dari pemilihan jawaban tersebut. Peserta didik dengan pemahaman konsep yang matang tidak akan kesulitan dalam menuliskan alasan dari jawaban yang sudah ditentukannya.

Materi yang digunakan pada soal adalah materi kelas VII semester ganjil meliputi objek IPA dan pengamatannya; klasifikasi materi dan perubahannya; suhu dan perubahannya; kalor dan perpindahannya; energi dalam sistem kehidupan. Pada asesmen yang dikembangkan, soal-soal IPA tidak lagi disajikan secara terpisah menjadi bidang fisika, 
kimia, dan biologi melainkan merupakan satu kesatuan utuh yang saling memiliki kaitan dalam penyelesaian permasalahannya. Hal ini diharapkan dapat memudahkan peserta didik dalam menemukan sendiri dan memahami konsep-konsep IPA secara holistik, bermakna, dan aktif (Listyawati, 2012). Pada asesmen, disediakan suatu kasus nyata yang sering terjadi di lingkungan sekitar peserta didik yang dapat digunakan untuk menjawab beberapa soal. Penyajian soal dibuat menarik dan disesuaikan dengan bahasa yang mudah dipahami oleh peserta didik pada usia SMP. Topik serta permasalahan-permasalahan yang disajikan pada soal juga merupakan kejadian sehari-hari yang dekat dengan pengalaman peserta didik sehingga dapat meningkatkan sikap peduli terhadap lingkungan (Lathifah \& Wilujeng, 2016). Secara tidak langsung hal ini merupakan langkah awal serta proses untuk meningkatkan peran peserta didik dalam melestarikan alam sekitar.

Tabel 5. Contoh Pengembangan Soal pada Asesmen Integrated Science berbasis PISA

\begin{tabular}{|c|c|c|}
\hline $\begin{array}{c}\text { Nomor } \\
\text { Soal }\end{array}$ & Indikator Soal & Soal \\
\hline 24 & $\begin{array}{l}\text { Disajikan satu } \\
\text { contoh kasus konsep } \\
\text { energi dalam } \\
\text { kehidupan sehari- } \\
\text { hari, peserta didik } \\
\text { mampu mendesain } \\
\text { cara-cara untuk } \\
\text { menyelesaikan suatu } \\
\text { permasalahan secara } \\
\text { ilmiah }\end{array}$ & $\begin{array}{l}\text { Rancangan penelitian yang dapat dilakukan untuk membuktikan } \\
\text { bahwa peningkatan kadar } \mathrm{CO}_{2} \text { mempengaruhi fotosintesis yaitu.... } \\
\text { a. Dua pot tanaman di letakkan di tempat terbuka dan disiram } \\
\text { dengan larutan gula yang kadarnya sama. } \\
\text { b. Dua wadah Hydrilla sp. dengan ukuran yang sama di beri } \\
\text { larutan baking soda berbagai kadar } \\
\text { c. Tanaman cabai ditutup dengan bejana transparan dan tanaman } \\
\text { cabai yang diletakkan di tempat gelap } \\
\text { d. Menetesi dengan lugol pada daun tanaman cabai yang daunnya } \\
\text { ditutup dengan alumunium foil dan tidak ditutup }\end{array}$ \\
\hline
\end{tabular}

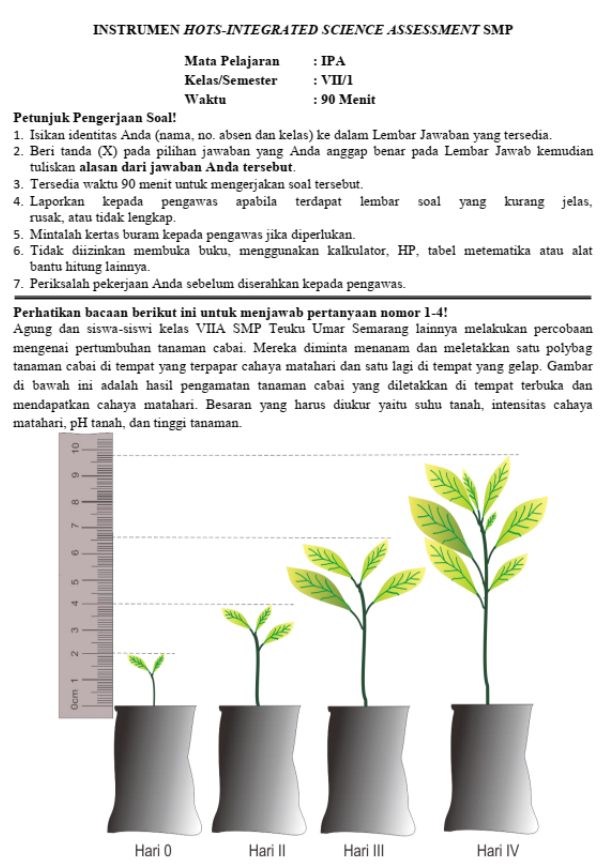

(1)

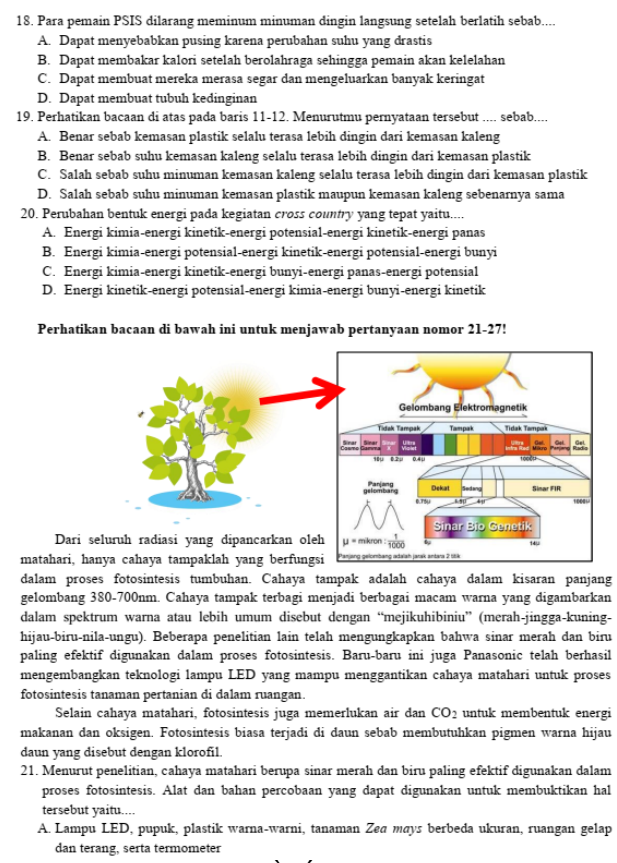

Gambar (1) Tampilan Halaman Petunjuk Pengerjaan Soal, (2) Tampilan Soal Integrated Science Asessment berbasis PISA

Sains sebagai proses merupakan metode atau cara agar peserta didik memperoleh pengetahuan baru (Nurfitriani, Wulan, \& Anggraeni, 2018) sehingga kemampuan berpikir peserta didik dapat meningkat melalui asesmen yang disajikan. Dengan integrated science assesment berbasis
PISA yang disajikan, peserta didik tidak hanya sebatas mengerjakan soal saja namun diajak pula mengenal hal-hal baru yang dapat mendorong mereka untuk menghubungkan pengetahuan yang dimiliki dengan hal-hal baru tersebut pada kehidupan sehari-hari. Selama ini soal-soal yang disajikan di sekolah seringkali 
hanya sebatas menuntut peserta didik menjawab sesuai dengan pengetahuan yang dimiliki yang berasal dari informasi yang diberikan guru maupun dari buku ajar. Hal ini membuat peserta didik kurang termotivasi sehingga pengetahuan yang dimiliki tidak berkembang. Peserta didik perlu dikenalkan dengan hal-hal baru untuk memperkaya keilmuan dan kemampuan berpikirnya semakin berkembang sehingga tidak kesulitan dalam memecahkan suatu permasalahan.

Pada gambar 1, terlihat bahwa asesmen yang dikembangkan dilengkapi dengan petunjuk pengerjaan yang jelas sehingga peserta didik tidak mengalami kesulitan dalam menjawab soal. Soal-soal yang disajikan dilengkapi dengan gambar untuk memperjelas pertanyaan ataupun pernyataan pada soal. Pada Gambar 1, disajikan suatu kasus untuk mengerjakan soal nomor 1 sampai dengan 4 . Dalam kasus tersebut seolah-olah peserta didik terlibat langsung dalam kegiatan yang digambarkan sehingga hal ini dapat mendekatkan peserta didik pada kegiatan sehari-hari. Sedangkan pada gambar 2, disajikan suatu informasi pendukung untuk mengerjakan soal nomor 21 sampai dengan 27 . Informasi tersebut sangat berkaitan dengan penerapan konsep fotosintesis dalam kehidupan sehari-hari. Berdasarkan informasi maupun kasus yang disajikan pada soal-soal asesmen integrated science, peserta didik diajak untuk menghubungkan pengetahuan yang dimiliki dan melakukan analisis yang tajam untuk dapat menjawab pertanyaan dengan tepat. Dengan satu permasalahan peserta didik harus menjawab soal dengan beberapa sudut pandang. Hal ini bersesuain dengan pernyataan Sari \& Wulanda (2019) yang menyatakan bahwa soalsoal yang disajikan berupa aplikasi konsep nateri IPA dalam kehidupan sehari-hari akan menuntut kemampuan berpikir tingkat tinggi dalam penyelesaiannya. Misalnya pada permasalahan Gambar 1, peserta didik diminta menentukan grafik laju pertumbuhan tanaman cabai dari hari ke hari, laju pertumbuhan rata-rata, pengukuran lebar daun cabai yang sudah tumbuh menggunakan jangka sorong, dan besaran pokok beserta alat ukur yang sesuai dengan kegiatan tersebut.

Asesmen mengadaptasi soal-soal PISA yang menuntut peserta didik memiliki kemampuan literasi sains. Penilaian literasi sains tidak hanya mengukur tingkat pemahaman peserta didik terhadap kemampuan sains, tetapi mengukur cara mengaplikasikan pengetahuan dan proses sains dalam situasi lebih nyata menggunakan seluruh aspek dalam sains (Sumaryatun, Rusilowati, \& Nugroho, 2016).

Dengan soal tersebut, kemampuan literasi sains mampu ditingkatkan dengan cara mengajak peserta didik lebih mengenal lingkungan sekitar, menginvestigasi serta menarik kesimpulan (Lutfi et al., 2017; Mardhiyyah et al., 2016) dalam setiap kasus yang disajikan pada soal, sehingga pembelajaran IPA dapat lebih optimal dan bermakna (Rakhmawan et al., 2015).

Validasi produk integrated science assesment berbasis PISA yang dikembangkan ditinjau dari komponen isi yang terdiri dari 20 indikator penilaian, komponen penyajian terdiri dari 7 indikator penilaian, serta komponen bahasa yang terdiri dari 4 indikator penilaian. Skor yang diperoleh pada setiap komponen kemudian dikonversikan menjadi nilai skala empat. Hasil validasi integrated science assesment berbasis PISA dari ahli materi dan ahli evaluasi pada komponen isi, penyajian, dan bahasa disajikan pada Gambar 3.

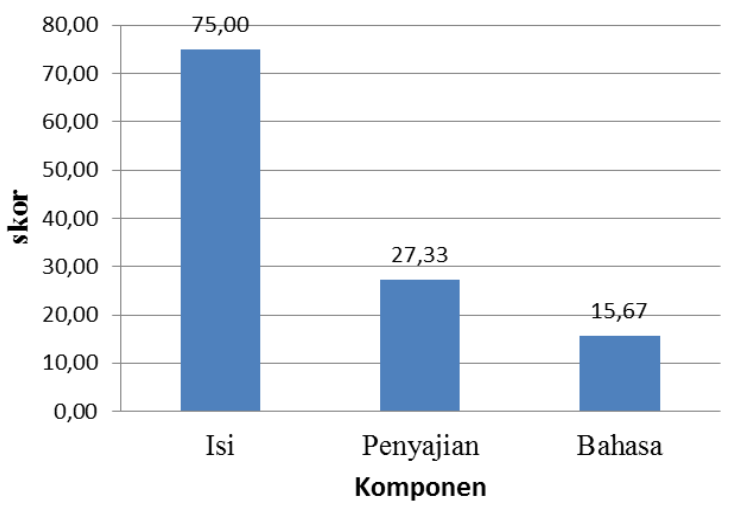

Gambar 3. Hasil Validasi Integrated Science Assesment Berbasis PISA oleh Ahli Materi dan Evaluasi

Berdasarkan Gambar 3, terlihat bahwa pada komponen isi dengan skor maksimal 80, diperoleh skor 75 yang masuk dalam kategori sangat baik. Pada komponen penyajian dengan skor maksimal 28, diperoleh skor 27,33 dalam kategori sangat baik. Sedangkan untuk komponen bahasa dengan skor maksimal 16, diperoleh skor 15,67 dengan kategori sangat baik juga. Penilaian komponen isi menggunakan 20 indikator yang dijabarkan dari tiga kompetensi PISA yaitu 1) Menjelaskan fenomena ilmiah; 2) Mengevaluasi dan mendesain penyelidikan ilmiah; 3) Menginterpretasikan data dan bukti secara ilmiah. Komponen penyajian dinilai berdasarkan tujuh indikator yaitu, 1) penyajian 
secara sistematis; 2) menggunakan tampilah yang menarik; 3) menggunakan kata-kata familiar (tidak asing) dengan peserta didik; 4) dilengkapi dengan gambar, tabel, dan sejenisnya yang mampu memperjelas maksud soal; 5) dapat menuntun peserta didik menggali informasi; 6) variatif; 7) komunikatif. Komponen bahasa dinilai dari empat indikator yaitu, 1) Penggunaan bahasa sesuai dengan kaidah Bahasa Indonesia; 2) Penggunaan bahasa mudah dipahami; 3) Penggunaan bahasa komunikatif; 4) Tidak terdapat kalimat ambigu (memiliki makna ganda) dalam soal.

Selain divalidasi oleh ahli materi dan evaluasi, produk pengembangan integrated science assesment berbasis PISA juga dinilai oleh dua orang guru sebagai pengguna. Dua orang guru yang menilai asesmen tersebut yaitu guru IPA SMP Nurul Islam dan guru IPA dari MTs Al Khoiriyyah. Berdasarkan hasil penilaian guru dapat dilihat pada Gambar 4 .

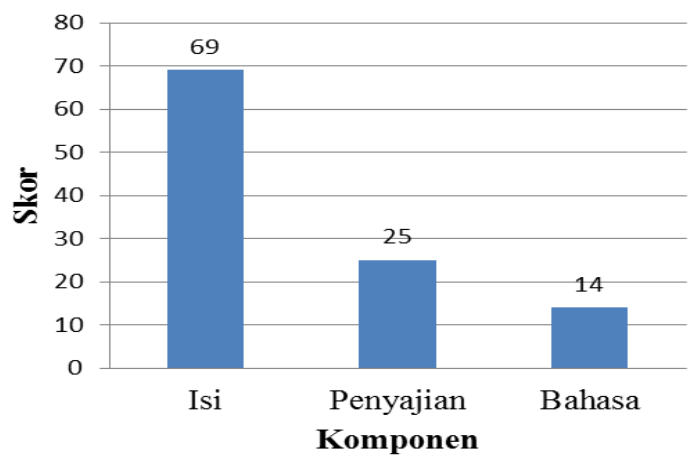

Gambar 4. Hasil Penilaian Guru IPA SMP terhadap Integrated Science Assesment Berbasis PISA

Gambar 4 menunjukkan bahwa pada komponen isi skor yang diperoleh adalah 69 pada kategori sangat baik. Pada komponen penyajian skor 25 dengan kategori sangat baik, dan komponen bahasa skor 14 dengan kategori sangat baik.

Berdasarkan hasil validasi ahli dan penilaian dari guru IPA SMP menunjukkan bahwa integrated science assesment berbasis PISA yang dikembangkan layak digunakan oleh guru. Penilaian dari peserta didik tidak kalah penting untuk dilakukan agar mendapat masukan dari pengguna secara langsung. Maka dari itu, tahap selanjutnya yaitu dilakukan uji keterbacaan terhadap 20 peserta didik kelas VII yang ada di MTs Al Khoiriyyah. Hasil respon peserta didik diperoleh rata-rata skor 8 dari 11 poin yang disediakan. Hal ini menunjukkan bahwa respon peserta didik terhadap integrated science assesment berbasis PISA yang dikembangkan dalam kategori baik.

Revisi produk integrated science assesment berbasis PISA dilakukan berdasarkan kritik dan saran yang dilakukan ahli materi, ahli evaluasi, guru IPA SMP dan peserta didik. Contoh revisi produk yang dilakukan disajikan pada Tabel 6.

Tabel 6. Contoh Revisi Produk Integrated Science Asessment berbasis PISA

\begin{tabular}{|c|c|c|}
\hline $\begin{array}{l}\text { No. } \\
\text { soal }\end{array}$ & Komentar & Hasil Revisi \\
\hline $1-4$ & $\begin{array}{l}\text { Besaran yang harus diukur belum } \\
\text { diungkapkan secara jelas. } \\
\text { Perhatikan bacaan berikut ini untuk menjawab pertanyaan nomor 1-4! } \\
\text { Agung dan siswa-siswi kelas VIIA SMP Teuku Umar Semarang lainnya melakukan percob } \\
\text { mengenai pertumbuhan tanaman cabai. Mereka diminta menanam dan meletakkan satu poly } \\
\text { tanaman cabai di tempat yang terpapar cahaya matahari dan satu lagi di tempat yang gelap. Gamba } \\
\text { bawah ini adalah hasil pengamatan tanaman cabai yang diletakkan di tempat terbuka } \\
\text { mendapatkan cahaya matahari. }\end{array}$ & $\begin{array}{l}\text { Melakukan perbaikan ditambah dengan besaran yang } \\
\text { harus diukur. } \\
\text { Perhatikan bacaan berikut ini untuk menjawab pertanyaan nomor 1-4! } \\
\text { ar Agung dan siswa-siswi kelas VIIA SMP Teuku Umar Semarang lainnya melakukan percobaan } \\
\text { ag mengenai pertumbuhan tanaman cabai. Mereka diminta menanam dan meletakkan satu polybag } \\
\text { d tanaman cabai di tempat yang terpapar cahaya matahari dan satu lagi di tempat yang gelap. Gambar } \\
\text { an di bawah ini adalah hasil pengamatan tanaman cabai yang diletakkan di tempat terbuka dan } \\
\text { mendapatkan cahaya matahari. Besaran yang harus diukur yaitu suhu tanah, intensitas cahaya } \\
\text { matahari, } \mathrm{pH} \text { tanah, dan tinggi tanaman. }\end{array}$ \\
\hline $13-16$ & 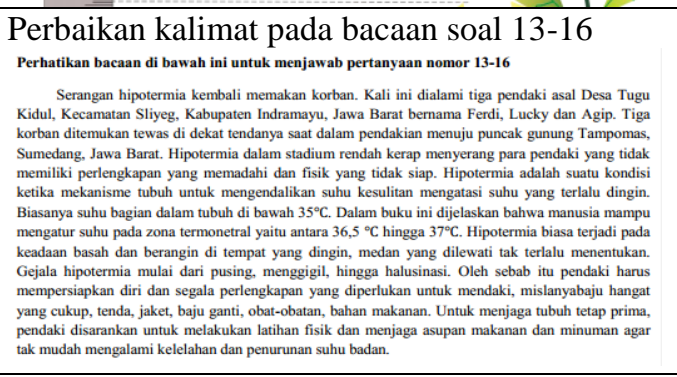 & 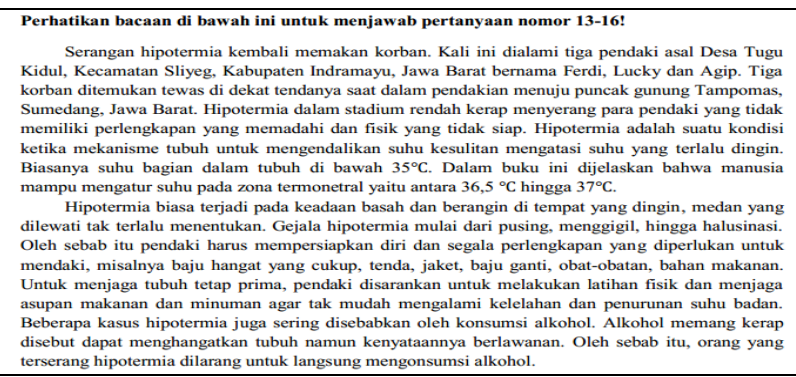 \\
\hline
\end{tabular}


Ada beberapa komentar peserta didik mengenai asesmen yang dikembangkan. Hal ini menjadi masukan dalam perbaikan asesmen, sehingga soal lebih mudah dipahami oleh peserta didik. Komentar-komentar tersebut diantaranya ada soal yang bahasanya sulit dimengerti peserta didik, serta ada pula soal yang dinilai bacaannya terlalu panjang. Padahal, hal-hal tersebut merupakan ciri khas dari soal-soal PISA. Peserta didik belum terbiasa menghadapi integrated science assesment berbasis PISA sehingga menganggap soal-soal tersebut rumit. Sesuai dengan penelitian Rohana, Rusilowati, dan Khumaedi, (2018) yang menyatakan bahwa kemampuan literasi sains peserta didik pada soal PISA tergolong rendah.

\section{Simpulan dan Saran}

Simpulan

Berdasarkan hasil penelitian dan pembahasan dapat disimpulkan bahwa integrated science assesment berbasis PISA yang dikembangkan valid dan dalam kategori sangat baik. Respon peserta didik terhadap integrated science assesment berbasis PISA dalam kategori baik. Dengan demikian asesmen yang dikembangkan layak digunakan oleh guru dalam pembelajaran.

Saran

Saran yang dapat disampaikan pada penelitian ini, perlu dilakukan penelitian selanjutnya untuk mengetahui keefektifan penggunaan integrated science assesment berbasis PISA dalam pembelajaran. Sebaiknya guru IPA SMP lebih sering memberikan latihan soal yang mengandung HOTS agar peserta didik lebih terbiasa menyelesaikan soal-soal tersebut sehingga kompetensi yang diharapkan pada kurikulum 2013 dapat tercapai dengan baik.

\section{Ucapan Terima Kasih}

Penelitian ini dibiayai oleh Kemenristekdikti dalam Hibah Penelitian Dosen Pemula pada tahun anggaran 2019. Kami mengucapkan terima kasih kepada Kemenristekdikti atas pendanaan penelitian; guru dan peserta didik MTs Al Khoiriyyah Semarang, dan guru SMP Nurul Islam serta pihak-pihak yang telah berkontribusi dalam pelaksanaan penelitian ini yang tidak dapat kami sebutkan satu per satu.

\section{Daftar Pustaka}

Basam, F., Rusilowati, A., \& Ridlo, S. (2016). Profil kompetensi sains siswa dalam pembelajaran literasi sains berpendekatan inkuiri saintifik. Pancasakti Science Education Journal, 7(1), 1-8. https://doi.org/10.24905/psej.v3i1.800

Direktorat Pembinaan SMA. (2010). Juknis penyusunan perangkat penilaian afektif di SMA. Jakarta: Direktorat Pembinaan SMA.

Haristy, D. R., Enawaty, E., \& Lestari, I. (2013). Pembelajaran berbasis literasi sains pada materi larutan elektrolit dan non elektrolit di SMA Negeri 1 Pontianak. Jurnal Pendidikan Dan Pembelajaran, 2(12), 1-13.

Kurniawan, T. D., \& Triharsiwi, T. (2016). Pengaruh penggunaan media video pembelajaran terhadap prestasi belajar ilmu pengetahuan sosial siswa kelas V SD se-kecamatan Gedangsari Gunungkidul tahun ajaran 2015/2016. Trihayu: Jurnal Pendidikan Ke-SD-An, 3(1), 21-26. https://doi.org/10.30738/trihayu.v3i1.739

Lathifah, I. N., \& Wilujeng, I. (2016). Pengembangan Perangkat Pembelajaran Integrated Science Berbasis Kearifan Lokal The Development of Learning Kit of Integrated Science Based on Local Wisdom. Jurnal Pendidikan Matematika Dan Sains, 4(2), 120-129. https://doi.org/10.21831/jpms.v4i2.12943

Listyawati, M. (2012). Pengembangan perangkat pembelajaran IPA terpadu di SMP. Journal of Innovative Science Education, 1(1), 61-69.

Lutfi, Ismail, \& Azis, A. A. (2017). Pengaruh project based learning terintegrasi stem terhadap literasi sains, kreativitas dan hasil belajar peserta didik. Prosiding Seminar Nasional Biologi Dan Pembelajarannya, 189-194.

Mardhiyyah, L. A., Rusilowati, A., \& Linuwih, S. (2016). Pengembangan instrumen asesmen literasi sains tema energi. Journal of Primary Education, 5(2), 147154.

Nurfitriani, Wulan, A. R., \& Anggraeni, S. (2018). Pengembangan asesmen kinerja untuk menilai ketrampilan proses sains terintegrasi siswa pada konsep ekosistem. Assimilation: Indonesian Journal of 
Biology Education, 1(1), 33-38.

Nurwahidah, I. (2017). Penggunaan asesmen pembelajaran IPA bagi siswa visual impairment di SLB Jawa Tengah. JIPVA (Jurnal Pendidikan IPA Veteran), 1(1), 39-50.

Nurwahidah, I. (2018). Pengembangan soal penalaran model TIMSS untuk mengukur high order thinking (HOT). Thabiea : Journal of Natural ScienceTeaching, 01(01), 20-29. https://doi.org/10.21043/thabiea.v1i1.3874

Rahmawati, I. L., Hartono, \& Nugroho, S. E. (2015). Pengembangan asesmen formatif untuk meningkatkan kemampuan self regulation siswa pada tema suhu dan perubahannya. Unnes Science Education Journal, 4(2), 842-850. https://doi.org/10.15294/usej.v4i2.7922

Rakhmawan, A., Setiabudi, A., \& Mudzakir, A. (2015). Perancangan pembelajaran literasi sains berbasis inkuiri pada kegiatan laboratorium. Jurnal Penelitian Dan Pembelajaran IPA, 1(1), 143. https://doi.org/10.30870/jppi.v1i1.331

Ranaweera, A. . (1976). Integrated science in junior secondary school in sri lanka. In The unesco Press.

Ristina, H., Linuwih, S., \& Nuswowati, M. (2018). Journal of innovative science education SETS learning efficacy to improve students science literacy skills. Journal of Innovative Science Education, $7(2), 427-433$.

https://doi.org/10.15294/jise.v0i0.27905

Rohana, I. N., Rusilowati, A., \& Khumaedi. (2018). Pengembangan tes untuk mengukur kemampuan literasi sains siswa SMP pada materi getaran dan gelombang. Unnes Physics Education Journal, 7(3), $1-10$.

https://doi.org/http://dx.doi.org/10.1089/ar s.2015.6320

Rohmawati, E., Widodo, W., \& Agustini, R. (2018). Membangun kemampuan literasi sains siswa melalui pembelajaran berkonteks socio-scientific issues berbantuan media weblog. Jurnal Penelitian Pendidikan IPA, 3(1), 8. https://doi.org/10.26740/jppipa.v3n1.p814

Saptono, S., Rustaman, N. Y., Saefudin, \&
Widodo, A. (2013). Model integrasi atribut asesmen formatif (IAAF) dalam pembelajaran biologi sel untuk mengembangkan kemampuan penalaran dan berpikir analitik mahasiswa calon guru. Jurnal Pendidikan IPA Indonesia, 2(1), 31-40.

https://doi.org/10.15294/jpii.v2i1.2507

Sari, D. S., \& Wulanda, M. N. (2019).

Pengembangan lembar kerja mahasiswa berbasis proyek dalam meningkatkan kemampuan berfikir kreatif mahasiswa. Natural: Jurnal Ilmiah Pendidikan IPA, 6(1), 20-33.

https://doi.org/10.30738/natural.v6i1.4073

Setiawan, H., Diah, N., Lestari, S., Studi, P., Matematika, P., Matematika, L., \& Tingkat, K. B. (2014). Soal Matematika dalam PISA Kaitannya dengan Literasi Matematika dan Keterampilan Berpikir Tingkat Tinggi. Prosiding Seminar Nasional Matematika, Universitas Jember, (November), 244-251.

Situmorang, R. P. (2017). Integrasi literasi sains peserta didik dalam pembelajaran sains. Satya Widya, 32(1), 49-56. https://doi.org/10.24246/j.sw.2016.v32.i1. p49-56

Sukardiyono, \& Rosana, D. (2018). Implementation of integrated science instruction assessment as an alternative to measure science process skills and social attitudes. Journal of Sciece Education Research, 1(1). https://doi.org/10.21831/jser.v1i1.16185

Sumarti, S., Rahayu, Y. S., \& Madlazim. (2015). Pengembangan perangkat pembelajaran berbasis inkuiri terbimbing untuk melatih literasi sains siswa. Jurnal Penelitian Pendidikan Sains, 5(1), 822829.

Sumaryatun, Rusilowati, A., \& Nugroho, S. E. (2016). Pengembangan instrumen penilaian autentik kurikulum 2013 berbasis literasi sains pada materi bioteknologi. Journal of Primary Education, 5(1), 66-73.

Tihardila, R., Marpaung, R. R. T., \& Achmad, A. (2018). Kesulitan guru IPA SMP seKecamatan Enggal dalam merencanakan dan melaksanakan asesmen. Jurnal Bioterdidik: Wahana Ekspresi Ilmiah, 6(4). 
Jurnal Pendidikan Sains (JPS) Vol 7 No 2 Oktober (2019) 147-156

Wardhani, S. (2008). Standar Penilaian

Pendidikan. Pusat Pengembangan dan

Pemberdayaan Pendidik dan Tenaga

Kependidikan Matematika.
Yuliati, L. (2013). Efektivitas Bahan Ajar IPA

Terpadu Terhadap Kemampuan Berpikir Tingkat Tinggi Siswa SMP. Jurnal

Pendidikan Fisika Indonesia, 9(1), 53-57. 